\title{
NAGYSZILÁRDSÁGÚ AUTÓIPARI LEMEZEK HAJLÍTÁSA, VISSZARUGÓZÁSI PROBLÉMAKÖRE
}

\section{BENDING OF HIGH-STRENGTH AUTOMOTIVE SHEET MATERIALS, AND SPRING-BACK PROBLEMS}

\author{
Béres Gábor $^{1}$, Danyi József ${ }^{1}$, Végvári Ferenc ${ }^{1}$ \\ ${ }^{1}$ Kecskeméti Föiskola, Gépipari és Automatizálási Müszaki Föiskolai KAR, Anyag- \\ technológia Tanszék, Magyarország, 6000. Kecskemét, Izsáki út 10. Telefon: +36- \\ 76/516377,levelezési cím, beres.gabor@gamf.kefo.hu
}

\begin{abstract}
The main aim of the automotive material innovations is to reduce car weight. This is necessary for reducing fuel consumption and poison gas emission. It is possible by using of thinner but higher strength sheet materials. Generally the higher strength coupled with less formability, which would leads to further technological problems, such as spring-back after bending. The heavy loaded, and in passenger-safety aspect relevant elements frequently consist of welded sheets, so-called Tailor Welded Blanks. The components could have different strength and sometimes different thickness too. In those cases, the spring-back requires special attention.
\end{abstract}

Keywords: automotive sheet materials, strength and ductility, spring-back.

\section{Összefoglalás}

A jármüipari anyagok fejlesztésének és alkalmazásuknak a célja a jármüvek tömegének csökkentése. A kisebb tömegủ jármủvek üzemanyag fogyasztása kisebb, és kisebb az általuk kibocsátott mérgező gáz mennyisége is. A kisebb jármütömeg vékonyabb, de nagyobb szilárdságú anyagok, pl. lemezek alkalmazásával érhető el. Az új, nagyszilárdságú lemezek alakíthatósága viszont kisebb, mint a lágy anyagoké, ezért használatuk technológiai problémákat vet fel. Ilyen például az alakításnál bekövetkező visszarugózás. Gyakran alkalmazzák, az un. tailored, azaz hegesztett lemezeket. Ezeknél, az alakítandó darab terítéke különböző szilárdságú lemezek összehegesztésével készül. Ez esetben a hajlításnál jelentkező visszarugózás különösen nagy gondot okoz.

Kulcsszavak: jármüipari lemezek, szilárdság és alakithatóság, visszarugózás.

\section{Bevezetés}

A jármüipar területén egyik legfontosabb kérdés a jármüvek tömegének csökkentése. Ezzel ugyanis kisebb üzemanyag fogyasztás és kisebb káros anyag kibocsátás érhető el. Fontos azonban, hogy a kisebb tömegü jármü is megfelelő védelmet biztosítson a gépkocsival utazók számára. Ha a jármü teherhordó vázelemei vékonyabb lemezből készülnek, a lemezanyagnak feltétlenül nagyobb szilárdságúnak kell lennie. Az utóbbi időben rendkívüli fejlődés volt tapasztalható az új, nagyszilárdságú (HSS), sőt, az ultra nagyszilárdságú (UHSS) lemezanyagok kifejlesztése területén. A lemezanyagok szilárdságának növelésével együtt jár alakíthatóságuk csökkenése. Ez a 
lemezek feldolgozása során gondot okozhat (1. ábra). [1]

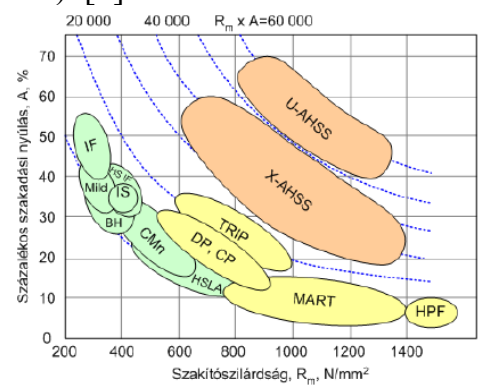

1. ábra. A jármüiparban használt lemezanyagok

\subsection{Lemezek visszarugózása hajlítás- nál}

A gyakorlatban alkalmazott szerkezeti anyagaink képlékeny alakítással történő megmunkálása során, a darab alakváltozása rugalmas és képlékeny alakváltozási komponensekből tevődik össze. A terhelő, alakító erő megszünésekor az összalakváltozás rugalmas összetevője csökken, amely következtében az alakított darab mérete megváltozik. Ez egyszerüen szemléltethető pl. egy lágyacél próbatest szakító diagramján (2. ábra). [2]

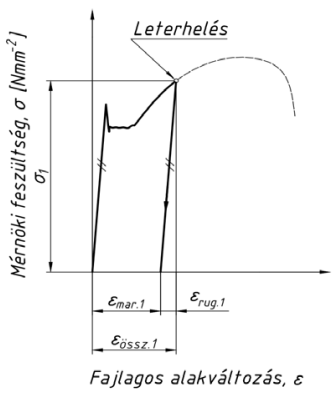

2. ábra. Rugalmas és képlékeny alakváltozás szakitóvizsgálatnál

A hajlító szerszámban meghajlított lemez, az erö megszünése után kinyílik, viszszarugózik. A müveletre jellemző feszültségi és alakváltozási állapotból adódóan, a hajlított lemezben az ún. semleges szál környezetében mindig marad egy rész $\left(\mathrm{s}_{\mathrm{r}}\right)$, amely csak rugalmas alakváltozást szenved
(3. ábra). Ez a része a lemeznek, próbál kiegyenesedni, az általa képviselt nyomatékkal nyit is a hajlított lemezen, ezzel hozzájárul a lemez visszarugózásához. Mivel azonban a rugalmasan alakváltozott réteg, csak kis része a lemezvastagságnak, a lemez kiegyenesedni nem tud, maradó feszültség keletkezik a hajlított darabban.

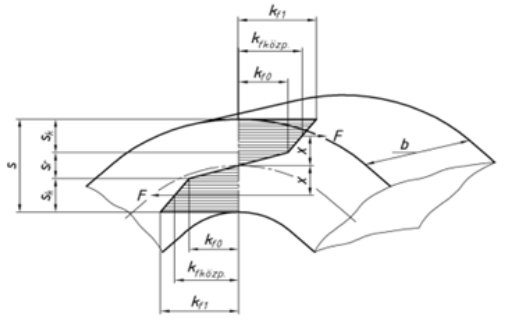

\section{3. ábra. A hajlitott lemezben ébredö érintö irányú feszültségek}

Ahhoz, hogy az elöírt munkadarabot méret és alakpontosan állítsuk elő, a visszarugózás mértékét, illetve mértékének függését a technológiai és szerszámozási paraméterektől és az alakított anyag tulajdonságaitól, ismerni kell. Ennek birtokában lehet ugyanis több ismert módszer alkalmazásával - túlhajlítással, vasalással stb. - kiküszöbölni vagy mérsékelni a visszarugózás okozta alak és méret hibát.

\section{A visszarugózási szög kísérleti úton történő meghatározása}

A szakirodalomban található több, jól használható összefüggéssel a visszarugózási szögek számítással meghatározhatók [2,3]. Ennek ellenére, a gyakorlatban célszerü a sorozatgyártás megkezdése előtt próbahajlítást végezni. Rontja ugyanis a számítások megbízhatóságát több, az összefüggésekben figyelembe nem vehető körülmény. Ilyen lehet a lemezanyagok alakíthatósági tulajdonságaiban való szórás.

A vizsgált lemezek - mélyhúzó és DP-s lemezek (1. táblázat) - visszarugózási szögei, 3 és 5 mm-es sugáron történő hajlítások esetén, viszonyítási alapot szolgáltat- 
hatnak a hegesztett lemezeken mérhetö értékeket illetően. A hajlító müveleteket gépen végeztük a 4. ábrán látható szerAMADA HFE-50-20 típusú CNC vezérlésü számpárokkal.

1. táblázat. Homogén lemezek szabad hajlitásnál kapott visszarugózási szögei

\begin{tabular}{|c|c|c|c|c|c|c|c|c|c|}
\hline \multirow{2}{*}{ Anyag } & \multirow{2}{*}{$\mathbf{s}[\mathbf{m m}]$} & \multirow{2}{*}{$\begin{array}{l}\text { Rp0.2 } \\
\text { [Mpa] }\end{array}$} & \multirow{2}{*}{$\underset{[\mathbf{M p a}]}{\mathbf{R m}}$} & \multirow{2}{*}{$\begin{array}{l}\text { A80 } \\
\text { [\%] }\end{array}$} & \multirow{2}{*}{$\mathrm{Z}[\%]$} & \multirow{2}{*}{$\mathrm{n}$} & \multirow{2}{*}{$\mathbf{r}$} & \multicolumn{2}{|c|}{$\beta\left[^{\circ}\right]$} \\
\hline & & & & & & & & $r / \mathbf{s}=3$ & $\mathrm{r} / \mathrm{s}=\mathbf{5}$ \\
\hline DC04 & 1 & 180 & 310 & 43,0 & 55,0 & 0.221 & 1,14 & $0^{\circ} 25^{\prime}$ & $4^{\circ}$ \\
\hline DP450 & 1 & 300 & 490 & 27,0 & 60,2 & 0.160 & 1,08 & $3^{\circ} 30^{\prime}$ & $8^{\circ} 20^{\prime}$ \\
\hline DP600 & 1 & 450 & 670 & 18,7 & 60,0 & 0.140 & 0.788 & $6^{\circ} 35^{\prime}$ & $10^{\circ} 50^{\prime}$ \\
\hline DP800 & 1 & 600 & 870 & 13,7 & 53,7 & 0.102 & 0.758 & $7^{\circ} 20^{\prime}$ & $14^{\circ} 10^{\prime}$ \\
\hline DP1000 & 1 & 780 & 1045 & 11,3 & 50,0 & 0.057 & 0.733 & $10^{\circ}$ & $16^{\circ} 45^{\prime}$ \\
\hline
\end{tabular}
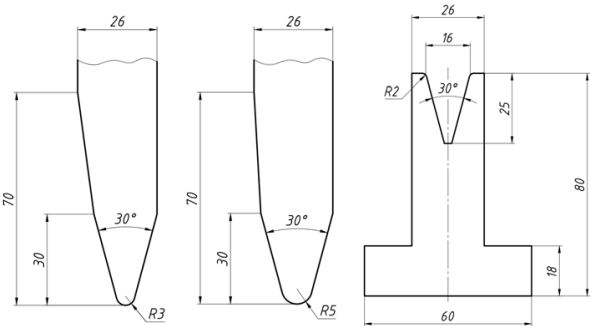

4. ábra. Hajlító szerszámok

A táblázat adataiból és az 5. ábrán a diagramból is látható a lemezanyag szilárdsága és a hajlítási sugár szerepe a visszarugózás mértékét illetően.

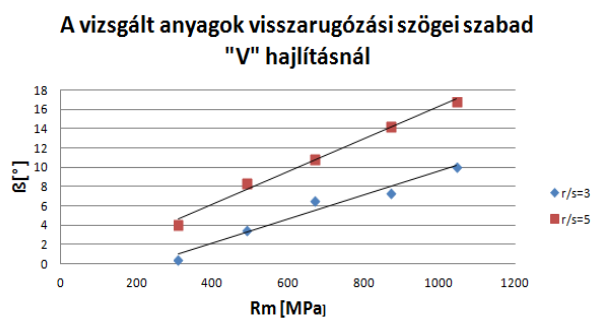

5. ábra. Homogén lemezek visszarugózási szögei

\section{Visszarugózás hegesztett leme- zek hajlításánál}

Sok esetben készülnek jármü karosszéria elemek különböző szilárdságú (egyes esetekben különböző vastagságú vagy eltérő bevonatú) lemezek összehegesztésével elöállított terítékekből. Ezeknél a terítékeknél különös jelentőséggel bír, és az eddigieknél is több figyelmet igényel a visszarugózás, kiváltképp a szerelő müveletek automatizálhatósága szempontjából. [4]

Hegesztett lemezek visszarugózásának vizsgálatára a 6. ábrán látható próbatesteket készítettünk. A hegesztett próbatestek hosszúsága a hajlítás tengelyével párhuzamos irányban 100, 200, 300, 400, 500, 600 $\mathrm{mm}$ volt. A visszarugózási szöget a varrat közvetlen közelében is mértük.

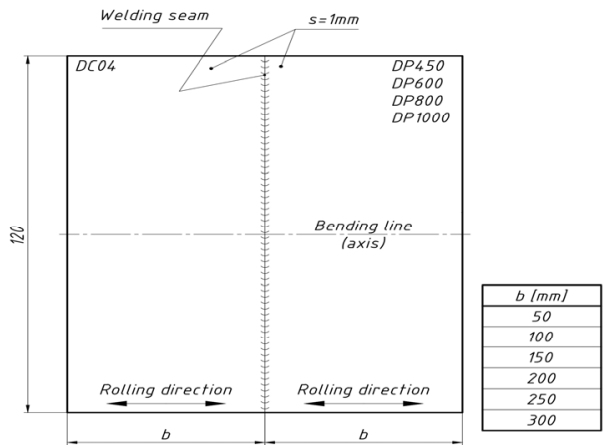

6. ábra. Hegesztett lemezek visszarugózásának méréséhez készitett próbatest

A hegesztett lemezek visszarugózási szög értékei a 7. és a 8. ábrán, a hegesztett és meghajlított lemezek pedig a 9. ábrán láthatók. 

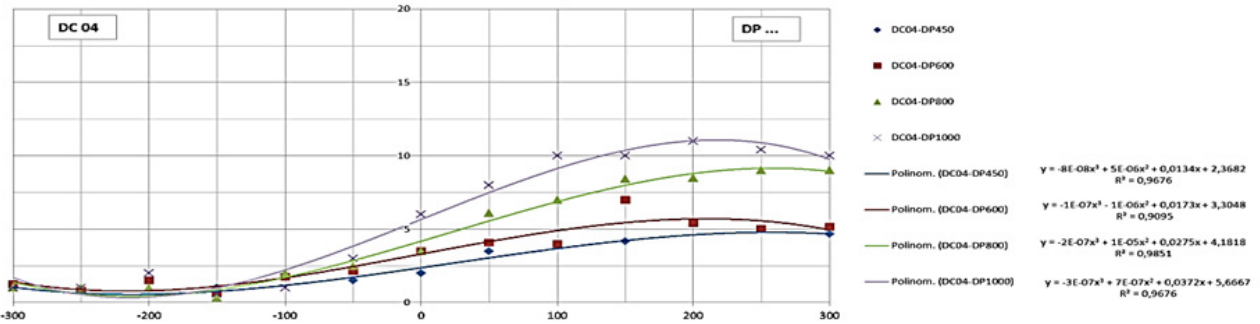

7. ábra. Hegesztett lemezek visszarugózása 3mm-es hajlitási sugárnál

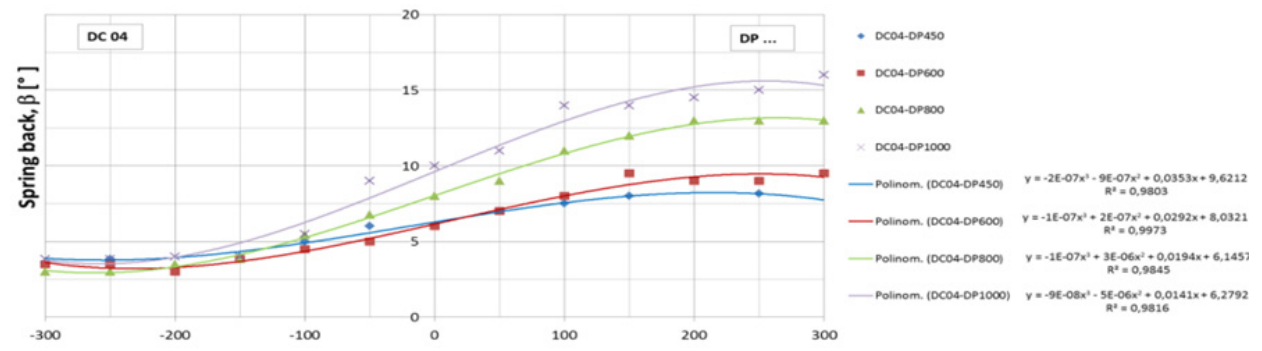

8. ábra. Hegesztett lemezek visszarugózása 5mm-es hajlitási sugárnál

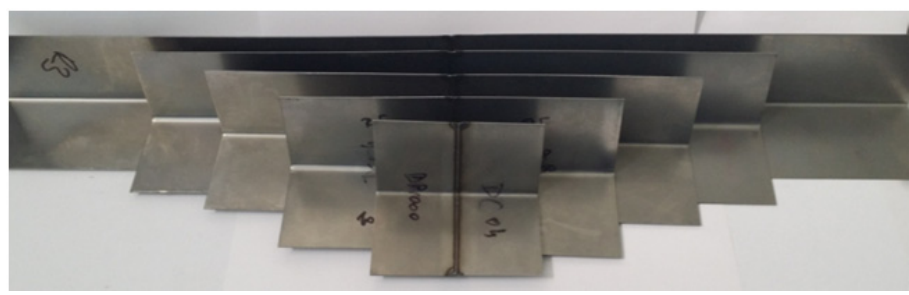

9. ábra. Hegesztett lemezek hajlitás után

\section{Következtetések}

Kísérleteinkből beigazolódott, hogy:

- a különböző szilárdságú hegesztett lemezek egyesítésének helyén a visszarugózási szög értéke jó közelítéssel a két lemezen mért visszarugózási szögek középértéke;

- hajlított alkatrészek gyártása szempontjából fontos információ, hogy a hegesztés vonalától 200-300 mm távolságra a lemezrészek egymásra hatása már nem jelentős;

- ez azonban azt is jelenti, hogy a hegesztett lemezek nem csak mérethibásak lehetnek, de a különböző mértékű vissza-rugózás alakhibát is okoz.

\section{Szakirodalmi hivatkozások}

[1] ThyssenKrupp Steel Europe

[2] Danyi, J., Végvári, F.: Jármügyártás és fenntartás, Elektronikus tankönyv, 2011.TÁMOP-4.1.2./A/2-10/1 2010-0018.

[3] Oehler. G, Kaiser. H.: Vágó-, sajtoló- és húzószerszámok. Műszaki kiadó, Budapest 190.-194. oldal

[4] http://incar.thyssenkrupp.com/4_02_060_QT 03 Sitzquertraeger-TB.html?lang=en

\section{Köszönetnyilvánítás}

A kutatómunka a TÁMOP-4.2.2.A-11/1/ KONV-2012-0029 projekt részeként, Az Új Széchenyi Terv keretében, az Európai Unió támogatásával, az Európai Szociális Alap társfinanszírozásával valósult meg. 